Meta

Journal des traducteurs

Translators' Journal

\title{
On Defining Translation
}

\section{Mariano García-Landa}

Volume 51, numéro 3, septembre 2006

URI : https://id.erudit.org/iderudit/013551ar

DOI : https://doi.org/10.7202/013551ar

Aller au sommaire du numéro

Éditeur(s)

Les Presses de l'Université de Montréal

ISSN

0026-0452 (imprimé)

1492-1421 (numérique)

Découvrir la revue

Citer cet article

García-Landa, M. (2006). On Defining Translation. Meta, 51(3), 435-444.

https://doi.org/10.7202/013551ar

\section{Résumé de l'article}

Dans le volume $50, \mathrm{n}^{0} 4$, décembre 2005, Maria Tymoczko nous présente brièvement quelques « Trajectoires de recherche en traductologie ». La première traite des tentatives de définir la traduction et l'auteur arrive à la conclusion qu'il s'agit d'une tâche difficile, voire impossible. J'essaie de démontrer ici qu'il est parfaitement possible de définir ce qu'est la traduction : au lieu de contempler le problème du point de vue de la traductologie, nous l'examinons du point de vue de la philosophie.
Ce document est protégé par la loi sur le droit d'auteur. L'utilisation des services d’Érudit (y compris la reproduction) est assujettie à sa politique d'utilisation que vous pouvez consulter en ligne.

https://apropos.erudit.org/fr/usagers/politique-dutilisation/ 


\title{
On Defining Translation
}

\author{
MARIANO GARCÍA-LANDA \\ Interprète de conférence, Belgique \\ monadri@skynet.be
}

\begin{abstract}
RÉSUMÉ
Dans le volume $50, n^{\circ} 4$, décembre 2005 , Maria Tymoczko nous présente brièvement quelques «Trajectoires de recherche en traductologie». La première traite des tentatives de définir la traduction et l'auteur arrive à la conclusion qu'il s'agit d'une tâche difficile, voire impossible. J'essaie de démontrer ici qu'il est parfaitement possible de définir ce qu'est la traduction: au lieu de contempler le problème du point de vue de la traductologie, nous l'examinons du point de vue de la philosophie.
\end{abstract}

\section{ABSTRACT but from the viewpoint of philosophy. \\ MOTS-CLÉS/KEYWORDS \\ translation, meaning, language games, perceptual systems, percepts}

In Volume 50, $n^{\circ}$ 4, December 2005, Maria Tymoczko traces some "Trajectories of Research in Translation Studies" and the first trajectory consisting in the difficulties even impossibility of defining translation. I try to show here that it is perfectly possible to define translation if you look at it, not from the viewpoint of "Translations Studies" aka Traductologie,

In Volume 50, $\mathrm{n}^{\circ}$ 4, December 2005, we find Maria Tymoczko's intervention in the plenary session of the International Conference "For a Proactive Translatology" celebrating the $50^{\text {th }}$ META Anniversary. Her presentation sums up the principal trajectories of research in translation studies that are likely to be productive in the coming decades and the first of those encompasses attempts to define translation. It would appear that there is no agreed definition of translation and what is more "such a definition is impossible because translation, like the concept game, discussed by Wittgenstein, is an open concept (Tymoczko 1998:654-56). In cognitive science such open concepts are sometimes called cluster concepts or cluster categories. Cluster concepts, such as the concepts game and language, both discussed by Wittgenstein, have certain interesting characteristics. In discussing language Wittgenstein remarks, "I am saying that these phenomena have no one thing in common which makes us use the same word for all, - but that they are related to one another in many different ways. And it is because of this relationship, or these relationships, that we call them all 'language" (Philosophical Investigations (PI) 1953: section 65, original emphasis). Wittgenstein indicates that a cluster concept such as game or language is comprised of "a complicated network of similarities overlapping and criss-crossing: sometimes overall similarities, sometimes similarities of detail... I can think of no better expression to characterize these similarities than 'family resemblances"' (PI 1953, section 66-67).

I must confess I was perplexed with the way Maria Tymoczko quotes those Wittgenstein sentences. Wittgenstein always uses the expression "language game" or "language games" whereas Maria Tymoczko separates those two words and speaks of 
'game' and then of 'language.' Why? If you separate those two words, you destroy Wittgenstein's concept of "language games." This is the more perplexing as in the very first paragraph of the same section 65 Wittgenstein uses the expression "languagegames" both in the German original: "Du redest von allen möglichen Sprachspielen, hast aber nirgendst gesagt, was denn das Wesentliche des Sprachspiels, und also der Sprache, ist" als in the English translation: "You talk about all sorts of language-games, but have nowhere said what the essence of a language-game; and hence of language, is..." It is true that in section 66 Wittgenstein refers to other games, not language-games, but games like board-games, card-games, ball games, Olympic games, but it is always in a pair of words: X-games and he, Wittgenstein, speculates that if they are all called "games" they must have something in common. Of course, Wittgenstein is not thinking here of including the language-games in the same category as all those other "games." We have to take into account the way Wittgenstein writes in the second part of his life. In contrast with the almost mathematical way of writing in the Tractatus when he was convinced of the truth of his simple propositions, the second Wittgenstein, who doubts everything, allows himself some literary frivolities like using the word "games" for something like "language uses." The reader has to take into account and make the necessary readjustments. "Language-games" are "language uses," also called "speech acts" in post-Wittgensteinian language philosophy ${ }^{1}$, referring to ways of using the language which means that language is a system that can be used in different ways. Indeed, Wittgenstein gives a list of examples of language uses in section 23:

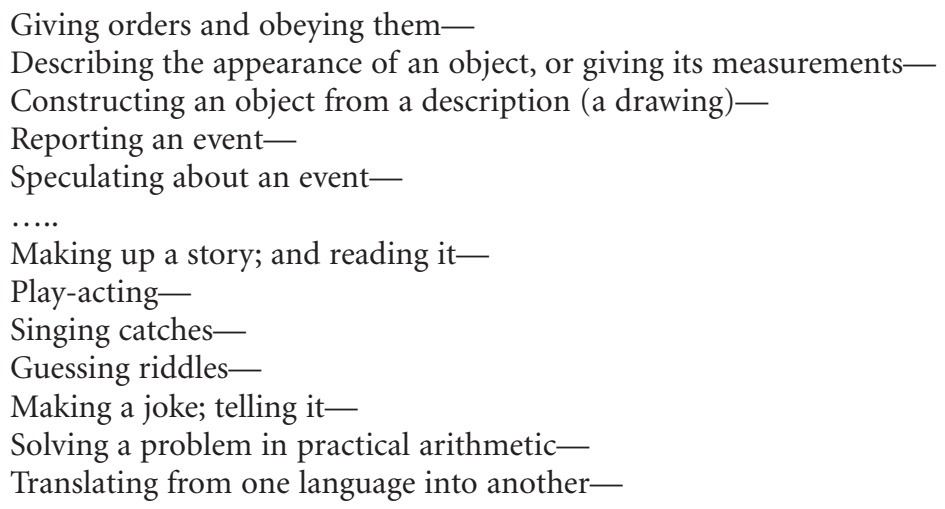

This means that you can do many things with a language by using it and you can only use it in a speech act (or language game). One of those uses is to translate from one language into another which means that translation is a language game or speech act or a series of speech acts. Now we have the beginnings of a definition of translation: Translation is a language game or speech act or a series of language games or speech acts which consist of saying in a given language what has been said in previous speech acts in another language.

\section{WE CAN GET NEARER TO THE REALITY OF LANGUAGE AND TRANSLATION}

Let me confess that I am also mystified by the fact that some translation theorists seem to discover aspects of translation that are in fact aspects of all "language games" not only of that language game that Wittgenstein calls translation. For example the 
'skopos theory' which is defined ${ }^{2}$ as "a translation theory that assigns great importance to the pragmatic aspects of the $<$ text $>$ and according to which the $<$ target text $>$ is essentially determined by its function with respect to the $<$ target audience $>$ and not solely by the properties of the $<$ source text $>$." This theory is presented as if the fact of taking into account the people to whom you address your speech or your text only applies to translation when in fact it happens in all "language games" (speech acts). You always speak to somebody even if this somebody is yourself (inner speech). It is impossible to speak, orally or in writing, without 'addressing' your speech or text to somebody, present or absent. The skopos theory was not invented by any traductologist but by the philosopher Emilio Betti in 1962. ${ }^{3}$

It is the other way round: all language games consist of a human being addressing another human being or human beings which explains why in the language game we call 'translating' we have the same situation, a human being called "text translator" or "conference interpreter" addressing other human beings. Text translators and simultaneous interpreters work in different social situations but they adapt consciously or unconsciously to the circumstances of their own productions and those circumstances include the human beings addressed. This is, as I said, Betti's skopos principle 4 also kown as the hermeneutic principle of applicatio although this one might appear at first sight to be slightly different. Gadamer, in his book Truth and Method (Wahrheit und Methode) contends that the meaning of a literary work is never exhausted by the intentions of its author ${ }^{5}$, the interpretation of future readers living in future moments, in different historical and cultural circumstances, will change the meaning of the work. A similar idea has also been developed by legal hermeneutics: the meaning of a law is not only the mens legislatoris or the mens legis but also (some say "above all") its application to a concrete case perhaps many years later. Please take note that we are now speaking of a phenomenon called 'meaning.' What affects those people you are talking to is not your sentences but what you mean with those sentences in that speech act as they experience it.

Some traductologists think that to translate is an action which has a communicative, a pragmatic and a semiotic dimension, and they are right, but it is because translating is a language game and all language games have those dimensions. And if this applies to all language games then Wittgenstein erred when he wrote that it is not possible to find rules common to all of them. All language games (speech acts) are linguistic transactions with a communicative, a pragmatic, a semiotic and a social dimension and these four dimensions mean that all language games are social transactions which produce social effects in some other people and/or the social circumstances of the speech act (or language game). Let us accept this for the time being until we take into account other general rules of all language games.

\section{WHAT IS MEANING?}

We have reached the conclusion that translation is just another form of language game but there are plenty of language games. How can we differentiate between them? By ascertaining what the people playing the language game want to do. People speaking to give orders play a language game called 'giving orders.' If you have been in the army you know what that is. People describing the appearance of an object, or giving its measurements are playing a language game which is called "describing the appearance 
or dimensions of an object." And this applies to all language games including those in the list Wittgenstein gives as examples of language games... except for the last one on that list which is translating. What are people doing when they play the game of translating? The answer is well known: it is obvious that people translating, orally or in writing, do not reproduce the linguistic structures like words or sentences, they reproduce something else, namely, 'what has been said.' This 'thing' has been called 'meaning,' 'le sens,' 'sensum.' Remember Jerome? Non verbum e verbo sed sensum exprimere de sensu. Translation is a transference or a reproduction of meanings and only that. And of course, there are hundreds of ways of doing that which is the subject matter of a science called Traductology or Translation Studies.

But if you think about it you will have to admit that in all language games there is a transference or reproduction of meaning, and not only in the translation game. People speaking to give orders play a language game called 'giving orders' but for these orders to be obeyed the soldier has to understand what the officer means, that is to say, to give orders you need a transfer of meaning because you have to understand the order to execute it. The same applies to people describing the appearance of an object, or giving its measurements, they are playing a language game which is called 'describing the appearance or dimensions of an object' but they have to get the meaning across to the people they are addressing. And the same happens to the whole list of examples of language games that Wittgenstein gives, except one called 'translation' and the difference is that in translation you only do one thing, namely, understand a meaning meant by a speaker or writer and you just transmit that meaning without doing anything with that meaning as the soldier does when he receives an order. Transmitting meanings is a case of pure communication.

In the translation game you have two successive language games (speech acts), a first language game where a speaker or writer transmits a meaning to somebody using a given sign system and a second language game where the text translator or the interpreter re-transmits that same meaning to other people using a different sign system. The conclusion is a general rule: in all language games there is a transference of meaning whether followed by an action or not but in the language game we call 'translation' there are two language games producing the same meaning with different sign systems and that's all. We should add this to the definition of translation but before doing that we have to ask ourselves seriously what is this so-called 'meaning' which is produced and transmitted in all language games and happens twice in the two interrelated language games we call 'translation' in its two forms: oral and written. The question is what is this 'meaning' that is produced and reproduced in all translation games?

\section{ARE WE TALKING OF MEANING OF WORDS AND SENTENCES?}

Wittgenstein has suggested a famous definition of 'meaning' in section 43 of the same book ${ }^{6}$ : For a large class of cases - though not for all - in which we employ the word "meaning" it can be defined thus: the meaning of a word is its use in the language" or as Valéry put it many years before: "le sens d'un mot est son emploi." We have to understand the expression "its use in the language" as "its use in a language game." The trouble with these two definitions of meaning and many others like them is that they are referring to the meaning of a word and this does not apply either to the simultaneous interpreter's job nor to the experience of the text translator. We do not translate 
words, do we? We translate.... What? We don't translate sentences either. Or shall I put it in a Wittgensteinian way and write: "in the great majority of cases we don't translate either words or sentences"?

But if this is so what do we transfer? For a conference simultaneous interpreter living in an oral word the answer is easy: we reproduce the meanings which is what the Speaker wanted to say in a more or less short series of oral speech acts. When you have to translate a whole text, what do you reproduce? Can you say that the text translator reproduces with another sign system the meanings produced in a previous series of written speech acts?

\section{THE BEST SOLUTION TO THE CONCEPT OF MEANING}

Is "meaning" a linguistic phenomenon? This is again easier to answer in the realm of orality where things happen like this: meaning meant by one and understood by the other is inseparable from the linguistic structures used but only for a short time because after a while the linguistic structures disappear and only the meaning remains in the memory of both the speaker and the hearer or at least in one of them. This is what is called the Jarvella Effect. ${ }^{7}$ It is obvious that this Jarvella Effect is a proof that the meaning meant and understood exists as an independent entity different from the linguistic structures because if the meaning meant were inseparable from the linguistic structures translation would be impossible. This is what seems to happen with sacred books like the Bible and the Koran where the meanings are supposed to be inseparably united with the linguistic structures but it does not happen in all the other cases. What shall we call this meaning that can be transported from one speech act in a given sign system to another speech act in a different sign system? Would it be useful to use the cognitivist term MR (Mental Representation)?

\section{COMRADE PAVLOV}

It was about midday of the $18^{\text {th }}$ day of June 1978, I had just finished the presentation of my $\mathrm{PhD}$ thesis and when I got out of the Sorbonne I found myself in the rue Saint Jacques, a street which runs parallel to the Sorbonne and ends in Santiago de Compostela. I came into the rue Soufflot in front of the Pantheon, which I have always considered the centre of Paris. I went down the Boul'Mich, walking towards the river. There are some bookshops there, I went into one of them, looked around, a book attracted my attention, a little book of the 'que sais-je' series, edited by the Presses Universitaires de France. The title was "Le langage et la pensée," author Paul Chauchard, first published in 1956. I went into a café and started reading. The second part is entitled 'Les mécanismes cérébraux du langage' (The brain mechanisms of language) and chapter two is entitled 'Le second système de signalisation' (The second signalization system). In page 60 I found this: If, at the physiological level, language is just a particular case of conditioned reflexes, it was to the credit of Pavlov to show that language is a very particular aspect of human conditioning which establishes the superiority of his psychism. For Pavlov and his disciples language is the second signalization system.

I went on reading and I found that with this word 'signalization,' Paul Chauchard was referring to the signals which are the main ingredients of perceptual systems so that, in the case of language, we can speak of second degree signals (first the noise, 
then the interpretation of that noise). There were some quotations of Pavlov himself and of some of his disciples like Follin and Ivanov Smolenski who developed Pavlov's idea. The second quote of Pavlov dated 1932 says: "If our sensations and representations referring us to our environment represent for us the first signals of reality, the concrete signals of language and, before everything else, the kinesthetic excitations (muscular feeling) going from the talking organs towards the cortex, are the second signals, the signals of signals.' They represent an abstraction of reality and make possible a generalization which is our specific thinking mode.."

I realized what this meant: what we call "language" is a second degree perception system, you perceive first noises and then, in a second perception phase, you perceive those noises as linguistic signs. Pavlov's two disciples played with this idea developing the formulation. I was flabbergasted. This changed everything: what we call 'language,' in orality for starters, is a second degree perception system and 'meaning' is the percept produced by the perception process of that second degree perception system. Does it sound too exotic to you? Why? After all there is a linguistic science called...

\section{PSYCHOLINGUISTICS}

...which deals with something called language perception and there are thousands of books on that subject ${ }^{8}$ but, funnily enough they deal only with the first stage of the whole process, the perception of linguistic noises. A classic book is Eric H. Lenneberg's Biological Foundations of Language with appendices by Noam Chomsky and Otto Marx, 1967, which is considered as the first stone of a new epoch in this discipline, full of interesting insights but unfortunately unable to disentangle the muddle between the word 'cognition' and the word 'language processing.' Lenneberg cannot see that these two words, cognition and language processing, refer to two aspects of the same perception phenomenon. Or the book by Herbert H. Clark and Eve V. Clark, Psychology and Language, An Introduction to Psycholinguistics,' 1977, where on page 407 you can read that The end of language is the communication of meaning. People talk in order to express the meaning of their thoughts, and they listen in order to discover the meaning of what others say. Without meaning there would be no real point in language. But what is meaning?... Bravo! That is the first time, if I am not mistaken, that psycholinguists say that the communication of meaning is the purpose of language. But here starts a new muddle. What you read in this quote sounds quite well but it is not perfect 'musically' speaking. I am going to play that same melody with variations: The end of language is the production of meaning, it being understood that production and communication are two different words referring to the same reality. People talk to communicate 'meanings,' not the 'meaning of thoughts' because meanings and thoughts are one and the same thing. And they listen in order to get the meaning meant by others. How does that sound? Better?

Another variation of the same melody: oral language is a second degree perceptual system which causes second degree percepts to produce communication which is the way humans live. People talk using linguistic-acoustic waves that produce in their interlocutors percepts (which are also called thoughts, concepts, impressions, visions, imagination, etc.) and they listen in order to receive and share with their interlocutor those percepts. Without those percepts there is no point in having and using that second degree perceptual system. 
Isn't it extraordinary that psycholinguists dealing with speech perception have not managed to discover that not only the beginning of that speech perception but the whole process is a perceptual process? And if it is a perceptual process it has to end necessarily with the production of a percept which is what we, simultaneous interpreters and text translators, call 'meaning.' Let us not forget that speaking of perception, there is a radical difference between the perceptual process and the final product. We are conscious of the final product or percept but fortunately not of the whole process.

\section{IT IS NOT SO EASY AS THAT}

It is my conviction that for scientific reasons it is better to concentrate first on the oral language games if we want to perceive clearly what 'meaning' is, but before that we have to take briefly into account writing and inner speech. To simplify matters, let me postulate in telegraphic style some general propositions to cover the whole conceptual field.

1. What we call 'language' in everyday parlance is in fact a species specific perceptual process of the homo loquens which has gone through a complex millenary evolution (something between more or less 200,000 years) in such a way that we can speak of how an acoustic perception process evolves into a second degree perception process (pure orality) followed thousands of years later by a third degree perception system which we call 'writing-reading' and finally followed by a fourth perception system called 'inner speech' (sometimes also called 'mind' or 'selfconsciousness').

2. Every perception process entails a relationship of the animal with its environment. The usefulness of the word 'intentionality', if we want to use it here, is that it adds the notion of activity of the animal to the idea of perception which otherwise seems to depict an animal which receives passively an influx of electromagnetic waves.

3. In every perception process we have three phases. First phase: there is first of all a series of electromagnetic waves coming from the environment and penetrating the brain setting in motion a process (Second Phase) which, guided by a 'mind,' ends in a Third Phase called a 'percept.' Nobody can deny that there is an obvious difference between the perception process and its result. The animal is not conscious of the process, only of the resulting percept. This is a description of a first degree perception process (animal perception) which homo loquens shares with many other species.

4. Each stream of perceptions is an event in time, it starts at a certain moment and it stops a bit later.

5. In the homo loquens second degree perception process, also known as orality, a stream of electromagnetic acoustic waves emanating this time not from the natural environment but from the social environment, that is, from a member of the same species, penetrates the brain of another member of that species setting in motion a complex perceptual process piloted by the $\operatorname{mind}^{9}$ that ends with the production of a percept containing a mass of information about the environment. The homo loquens is not conscious of the perceptual process but only of the resulting percept if at all. That is to say homo loquens in a second degree perception process is not aware of what grammarians and linguists call signs which are present in writing but which are not 
perceivable in the second degree perception process (pure orality) so that one could say, as Derrida does, ${ }^{10}$ that they do not exist at all in orality.

6. If the electromagnetic acoustic waves in this second degree perception process emanate, not from the natural environment but from another member of the homo loquens species, this means that they come from a social 'environment', not a natural one, and social 'environment' has an ontological status different from the natural or cosmic environment. This social 'environment' is called 'society' (I have found it useful to call it "injectivity" as opposed to "objectivity").

7. Also in this case we can say that this stream of perceptions is an event in time and space which is what we call the speech act ("language game"), a social transaction that presupposes the existence of a whole society (from the aboriginal tribe to the world society).

8. In the homo loquens third degree perception process the oral electromagnetic waves of the second degree perception process:

- are transformed into written signs and which are perceived as such by both communication poles in the writing act (writer-reader) and

- in order to decipher these signs both the writer and the reader unconsciously refer back to the oral value of those signs in a sort of retro-perception of the oral experience.

9. In what I call the homo loquens fourth degree perception process (inner speech) both oral and written signs are 'interiorized' in an inner mental communication process between two internalized social personae.

10. It must be understood that these three homo loquens perceptual systems produce, as I pointed out, a perception of a species specific 'environment' which is called 'society' and this society is a new ontological 'mass' ${ }^{\prime 1}$ in which we find actors acting in social spaces called 'situations.' The result is that the homo loquens lives in two different environments, a natural one, and a social one. These two environments transmit perceptual information that is further elaborated and accumulated in the constant communication network produced by the three species-specific perceptual systems: World Network of Speech Acts ("language games").

11. These two environments are as follows: first the natural environment called objective reality which exists without us (cosmos, including our body), and, second, society which I also call public subjective reality as opposed to objectivity, and this public subjective reality has in turn two aspects:

- a soft injectivity or mental aspect which includes masses of information, ${ }^{12}$ what we call the collective mind produced by the constant World Network of Speech Acts ("language games") connecting all languages through the mediation of translation in all its forms, and

- a second aspect, namely, all the artifacts we, societal animals, manufacture, like books, signs of all kinds, houses, roads, cars, chairs, computers, airports, theatres, swimming pools, pianos, atomic bombs, etc. which I call heavy injectivity because you can touch those artifacts. Needless to say, none of these artifacts would be there without society and its contents.

12. The workings and functioning of the homo loquens brain, and, therefore, of what we call 'mind,' depend on the information transmitted by perception received from 
the two above mentioned environments. It is impossible to understand the workings of the brain we call 'mind' without taking into account the constant information flowing into the brain through perception from the objective reality (natural environment or cosmos) and from the injective reality (society). The mind would not exist without this information coming from outside the body. The best thing is to consider the whole chain as a 'system' or better still as a 'field' which we could call the societyperception-language-mind system (SPLMS). My contention is that in order to understand what the so-called language and the so-called mind are you have to consider the totality of the SPLMS.

13. I postulate that the World Network of 'speech acts ("language games") creates a constant state of communication in all society -nowadays practically the whole planet- which is what I call soft injective reality.

\section{DEFINITION OF TRANSLATION}

First, a definition of the so-called language: what we call "language" is a perceptual system and therefore, there is a difference between the acoustic (or written) perceptual waves, the process of perception and the resulting percept.

Second, a definition of translation: translators reproduce with a second sign system (language) in a second speech act ('language game') the percepts produced by other speakers/writers in a first speech act ('language game') with a first sign system.

\section{NOTES}

1. John R. Searle, Speech Acts, An Essay in the Philosophy of Language, CUP, first published in 1969, that is, 16 years after the publication of Wittgenstein's Philosophical Investigations.

2. Jean Delisle, Hannelore Lee-Jahnke and Monique C.Corner, Translation Terminology, Volume I, page 179, published by John Benjamins Publishing Company, Amsterdam/Philadelphia, 1999.

3. Emilio Betti, Die Hermeneutik als allgemeine Methodik der Geisteswissenschaften, J.C.B.Mohr (Paul Siebeck), Tübingen, 1962.

4. Loc. cit.

5. Eagleton (1983): Literary Theory: An Introduction, Oxford, Basil Blackwell.

6. $\quad$ PI $=$ Philosophical Investigations.

7. After a while you remember the meaning but not the words. Jarvella, R. 1971 Syntactic processing of connected speech. Journal of Verbal Learning and Verbal Behavior, 10, 409--416.). The Jarvella Efect is what Danitsa Seleskovitch called "évanescence des mots" (evanescence of words) or "absence de trace mnésique" (absence of mnemonic mark) (Seleskovitch 1968). Seleskovitch's theory says that what leaves a "trace mnésique," are not the signs but the meaning. You remember what has been said but not the words or sentences. It is generally accepted, even by cognitive psychology, that verbal memory is weak and that the phonological sequences disappear after some seconds. Between 1970 and 1972 Jarvella did a series of experiments presenting speech or text to people and stopping them suddenly to ask them to repeat what they had just heard or read. Result: verbal memory of the last sentence or part of it was still rather good but not for the previous sentences. We can reach the conclusion that the comprehension process (or as I call it, the perceptual process) forgets the 'linguistic material' once the percept has been produced (once the meaning has been produced).

8. One of the latest is Handbook of Speech Perception, edited by David B.Pisoni and Robert Ellis Remez. Blackwell, published in February 2005 which is a collection of pieces by quite a number of people, all of them dealing with the first face of the language perception process, namely, auditory and speech processes, sensing speech, perceptual organization of speech, phonetic processing by the speech perceiving brain, perception of linguistic properties, perception of intonation, perception of voice quality, etc., anything except the final phase of the process which is the production of a percept because there is no perception without the production of a percept. 
444 MetA, LI, 3, 2006

9. Donald D. in Visual intelligence, How we Create what we See, 1998 enumerates a series of rules like this one: you construct visual worlds from ambiguous images in conformance to visual rules (Hoffman 98:24).

10. The exteriority of the signifier is the exteriority of writing in general, and I shall try to show that there is no linguistic sign before writing. Without that exteriority the very idea of the sign falls into decay. Derrida, Of Grammatology, English translation, page 14.

11. John P. Searle, The Construction of Social Reality, 1995.

12. Emile Durkheim writes: Social Life Is Constituted Wholly Of 'Collective Representations.' The Rules of Sociological Method, second edition, 1895. 